\title{
Morphological and Chemical Nature of the Sclerotia of Chainia olivacea Thirumalachar and Sukapure of the Order Actinomycetales
}

\author{
MARY P. LECHEVALIER, H. A. LECHEVALIER, AND CARYL E. HEINTZ' \\ Institute of Microbiology, Rutgers University, The State University \\ of New Jersey, New Brunswick, New Jersey 08903
}

\begin{abstract}
The biochemical properties of strains of most of the known species of Chainia Thirumalachar were compared. The mode of formation of sclerotia by a strain of C. olivacea Thirumalachar and Sukapure was studied by light and electron microscopy. Hyphae first show numerous lipid inclusions and then divide into cells in which lipid occupies more and more space. An intercellular cement is deposited forming a plurilocular structure. The lipids, which account for $50 \%$ of the weight of the biomass, are triglycerides of branched-chain fatty acids of the iso/anteiso series, principally $C_{15}$ and $C_{16}$. The intercellular cement is rich in L-2,3-diaminopropionic acid, an amino acid not previously found associated with microbial structures.
\end{abstract}

The genus Chainia was proposed by Thirumalachar in 1955 (38). The description of the new genus was as follows: "Mycelium well developed, fine, non-septate, growing into substrate, not forming true aerial mycelium, non-fragmenting, Gram-positive, non-acid fast, developing sclerotic granules composed of incurled hyphal cells, single or in aggregates, enveloped in hyphal sheath at first and later becoming free. Conidial form unknown. Type species 'Chainia antibiotica Thirum'."

Gattani (13) observed the production of sclerotic granules by two strains of Streptomyces griseus grown on Trypticase soy agar. The granules were initiated by the swelling of a hypha which became surrounded by others leading to formation of granules 12 to $45 \mu \mathrm{m}$ in diameter which could coalesce into small groups.

After the publication of the description of $C$. antibiotica in 1955, Thirumalachar distributed strains of this organism together with strains of two undescribed species, $C$. poonensis and $C$. olivacea. The latter was eventually described by Thirumalachar and Sukapure in 1964 (40). C. poonensis was never described by Thirumalachar, but a description of this organism was published by Kalakoutskii and Krasil'nikov in 1960 (22). Additional species were described as follows: C. violens (22), C. ochracea (24), C. flava, C. purpurogena (40), C. minutisclerotica (39), C. rosea, C. fumigata, and C. aurea (41)

\footnotetext{
${ }^{1}$ Present address: Department of Microbiology, University of Pennsylvania Dental School, Philadelphia, Pa. 19104.
}

Two other species of Thirumalachar, $C$. nigra and $C$. rubra, were described by Shirling and Gottlieb (35).

It soon became obvious to those who examined cultures of Chainia that the original description by Thirumalachar was misleading since strains of Chainia formed aerial mycelium bearing chains of conidia identical to those formed by strains of Streptomyces. In addition, strains of Chainia were found to have a cell wall composition identical to that of streptomycetes (4). Definition of the genus Chainia on the basis of production of sclerotia became difficult to accept especially since Baldacci et al. (2) confirmed Gattani's report that a large number of actinomycetes can form sclerotic granules.

The aim of the present study is to follow the mode of sclerotium formation in a strain of $C$. olivacea, to compare the chemical composition of the wall of the sclerotium with that of the hyphae of this organism, and to gain some knowledge about the nature of the lipids formed in the sclerotium.

\section{MATERIALS AND METHODS}

Organisms. Chainia olivacea strain V17676 was isolated from nondesertic soil by Enrique Tejera, National Institute of Hygiene, Caracas, Venezuela. All the other strains of Chainia reported here were our own soil isolates or were received from M. J. Thirumalachar or R. S. Sukapure of Hindustan Antibiotics Ltd., Pimpri (Nr. Poona), India. Strain numbers are those of the collection of the Institute of Microbiology of Rutgers University (IMRU) if not otherwise indicated. 
Growth and maintenance of cultures. Cultures were grown either from a freeze-dried stock or from stocks maintained on slants. All strains were maintained on yeast extract-dextrose (YD) agar slants (yeast extract, $10 \mathrm{~g}$; crude dextrose, $10 \mathrm{~g}$; agar, $15 \mathrm{~g}$; tap water, 1 liter, $\mathrm{pH} 7.2$ before sterilization) grown at $28 \mathrm{C}$ for 7 to 10 days. Sclerotia for chemical analyses were harvested by scraping 1-week-old growth on plates of Czapek $(\mathrm{Cz})$ agar (44) using the edge of a microscope slide or a scalpel. Vegetative cells used in the preparation of cell walls were grown for one week in Czapek broth on a reciprocal shaker (New Brunswick Scientific Co., New Brunswick, N. J., model 5713 operated at $60 \mathrm{strokes} / \mathrm{min}$ with a stroke length of 20 $\mathrm{cm})$.

Other media used for morphological studies were potato-carrot $(\mathrm{PC} ; 10)$, dilute potato-carrot (TPC), and water agar (WA) (21) made with either crude or Noble (Difco) agar and dilute Pablum (TPab; 29).

Physiology. The methods used were those of Gordon (16) and Gordon and Horan (17).

Whole-cell analysis. The procedures used were those previously described (27).

Cell wall preparation. Preparations and analyses of cell walls and sclerotial walls were made using the method described by Suput et al. (37) except that various methods of breakage had to be used. Vegetative cells of the substrain of V17676 which had lost the capacity to form sclerotia could be broken (like most actinomycetes) by sonic treatment for $10 \mathrm{~min}$. The vegetative cells of the substrain still capable of forming sclerotia withstood $30 \mathrm{~min}$ of sonic treatment and $30 \mathrm{~min}$ of grinding in a tissue grinder. Breakage was finally accomplished by grinding the cells with dry ice in a mortar and pestle. The sclerotia were broken by hand grinding in a tissue grinder for $30 \mathrm{~min}$ to $1 \mathrm{~h}$, the process of breakage being monitored with a microscope.

Lysozyme digestion. Treatment of sclerotia with lysozyme was carried out by shaking at $37 \mathrm{C}$ on three successive days with a fresh 0.1 to $0.2 \%$ lysozyme solution in $0.1 \mathrm{M}$ phosphate buffer $(\mathrm{pH} 7.0)$. The sclerotia were washed twice with $0.1 \mathrm{M}$ phosphate buffer ( $\mathrm{pH} \mathrm{8.0)}$ and once with water between each digestion. Hyphae were treated with lysozyme twice as described above, after which time the cell mass had diminished by about $95 \%$.

Chromatography of amino acids, sugars, and polyols. For paper chromatography the following systems were used: for sugars and polyols, $n$-butanol-pyridinewater-toluene $(5: 3: 3: 4)$ (37) (system 1); for amino compounds and polyols, $n$-butanol-pyridine-waterglacial acetic acid $(60: 40: 30: 3)$ (system 2) or methanol-water-10 N HCl-pyridine (80:17.5:2.5:10) (system 3). Polyols were revealed using ammoniacal silver nitrate or the Bean-Porter reagent (3); other compounds were detected with ninhydrin (amino acids and amino sugars) or acid aniline phthalate (sugars) (4).

Dinitrophenyl derivatives of amino acids. Dinitrophenyl (DNP) derivatives were prepared from pure substances or from the mixture of amino acids resulting from hydrolysis of the sclerotial wall using 1 $\mathrm{ml}$ of 1\% 1-fluoro-2,4-dinitrobenzene (FDNB) in ethanol and $10 \mathrm{ml}$ of $1.6 \% \mathrm{~K}_{2} \mathrm{~B}_{4} \mathrm{O}_{7}$ per $\mathrm{mg}$ of amino acid and heating $1 \mathrm{~h}$ in a water bath at 60 to $65 \mathrm{C}$. The reaction mixture was first extracted with ether to remove excess FDNB, acidified with $2 \mathrm{ml}$ of concentrated $\mathrm{HCl}$, and extracted with $1 \mathrm{ml}$ of isopropyl acetate $\left(I P A_{c}\right)$. The IPA $A_{c}$ extract was applied to a column of silica gel (J. T. Baker, Phillipsburg, N. J., 60-200 mesh), and the DNP from the reaction was eluted with the same solvent. The DNP amino acids were then eluted with methanol. Alternatively, purification and separation of the DNP derivatives were effected by preparative thin-layer chromatography on $\mathrm{PF}_{254}$ (Brinkmann Instruments, Inc., Westbury, N. Y.) in a chloroform:tert-amyl alcohol:glacial acetic acid $(70: 40: 3)$ system (system 4) and elution of the bands with methanol. The DNP derivatives were also chromatographed on Whatman no. 1 paper in a tert-amyl alcohol:pyridine:glacial acetic acid:water (110:1.0:0.08:25) mixture (system 5) (18) for $18 \mathrm{~h}$ at 25 C. All chromatography was carried out in the dark.

Determination of isomer of 2,3-diaminopropionic acid. The mixture of amino acids from acid hydrolysates of strain V17676 sclerotia were separated by preparative paper chromatography on water-washed Whatman no. 3 paper in system 3 by developing for 5 to $6 \mathrm{~h}$ at $25 \mathrm{C}$ and drying the sheets overnight in a current of air. The amino acids were located by spraying a small strip from the center of the sheet with ninhydrin and eluting the appropriate bands with distilled water. The aqueous eluate containing 2,3diaminopropionic acid $\left(\mathrm{DAP}_{\mathbf{r}}\right.$ ) (admixed with some L-2,6-diaminopimelic acid) was taken to dryness in vacuo. The residue, containing approximately $300 \mu \mathrm{g}$ of DAP , was incubated with shaking at $37 \mathrm{C}$ for $24 \mathrm{~h}$ in $1 \mathrm{ml}$ of $\mathrm{pH} 8.3 \mathrm{Na}_{4} \mathrm{P}_{2} \mathrm{O}_{2}$ buffer $\left(1.78 \mathrm{~g} \mathrm{Na}_{4} \mathrm{P}_{2} \mathrm{O}_{2}\right.$. $10 \mathrm{H}_{2} \mathrm{O}$ in $180 \mathrm{ml}$ water, adjusted to $\mathrm{pH} 8.3$ with $1 \mathrm{~N}$ $\mathrm{HCl}$ and diluted to $200 \mathrm{ml}$ ) containing $0.02 \mathrm{ml}$ of D-amino acid oxidase (crystalline, Sigma Chemical Co., St. Louis, Mo.) and $0.01 \mathrm{ml}$ of a 1:50 dilution of catalase (type C100, Sigma Chemical Co.) and tested for disappearance of the amino acid by chromatography.

Lipids. For comparison of total lipid content, air-dried cell material which had been ground with a mortar and pestle was extracted for 1 week at $25 \mathrm{C}$ with occasional shaking using a succession of solvents-methylene chloride-methanol $(1: 1)$, chloro form, and petroleum ether (boiling point 40-50 C)and then saponified with $0.5 \%$ ethanolic potassium hydroxide for $18 \mathrm{~h}$ at $37 \mathrm{C}$. The various extracts were taken to dryness in a stream of nitrogen and weighed. The butter-yellow lipids extracted from the sclerotia were saponified by heating on a steam bath for $5 \mathrm{~min}$ with $2 \%$ methanolic potassium hydroxide. The methanol was removed in vacuo with mild heat, and a mixture of distilled water and methylene chloride $(1: 1)$ was added. After acidfication of the aqueous

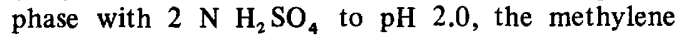
chloride-soluble material was methylated using boron trichloride methanol, purified by preparative thinlayer chromatography, and the methyl esters of the fatty acids were analyzed by gas chromatography as previously described (28).

The various steps of this procedure were monitored by thin-layer chromatography on Silica Gel $G$ or $\mathrm{PF}_{254}$ in a petroleum ether (boiling point 40-50 C):diethyl ether:glacial acetic acid system $(85: 15: 1)$ (system 6) using standard mono-, di-, and triglycerides, 
fatty acids, fatty acid methyl esters, and long-chain alcohols for comparison. Polyols freed during saponification were desalted on a column of Amberlite MB-3 and identified as described in a previous section. Phospholipids were visualized using the molybdenum blue reaction of Dittmer and Lester (31) and amino acid-containing lipids with $0.4 \%$ ninhydrin in watersaturated butanol. Standards were purchased from Applied Science Laboratories (State College, Pa.) and Analabs (North Haven, Conn.). Solvomercurationdemercuration was carried out overnight at room temperature on the fatty acid methyl esters by the procedure described by Gerber (14), modified by substituting $1 \% \mathrm{NaHCO}_{3}$ for the $10 \% \mathrm{NaOH}$ to prevent saponification of the esters.

Heat resistance. Vegetative and sclerotic cells were obtained as described above for cell-wall analysis. The cells were washed twice in sterile $0.1 \mathrm{M}$ phosphate buffer ( $\mathrm{pH} 7.0)$, resuspended in buffer, and heated in a water bath at $60 \mathrm{C}$ for $4 \mathrm{~h}, 70 \mathrm{C}$ for 15 and $30 \mathrm{~min}$, and $96 \mathrm{C}$ for $1 \mathrm{~min}$. At the end of this period the tubes were cooled immediately, inoculated onto YD agar, and incubated 3 weeks at $28 \mathrm{C}$.

Cells of Streptomyces fradiae IMRU 3535 grown shaken in YD liquid culture for $24 \mathrm{~h}$ were included for comparison.

Electron microscopy. Sclerotia were fixed on ice in either the formaldehyde-glutaraldehyde mixture of Karnovsky (23) for 1 to $18 \mathrm{~h}$ or the glutaraldehydeosmium tetroxide mixture of Franke et al. (11); both were buffered with $0.1 \mathrm{M}$ sodium cacodylate. After several buffer rinses, the sclerotia were placed in $1 \%$ buffered osmium tetroxide for 2 to $3 \mathrm{~h}$ on ice rinsed several times with buffer and then with distilled water. After $3 \mathrm{~h}$ at room temperature in $0.5 \%$ aqueous uranyl acetate, they were rinsed in distilled water and dehydrated either by (i) passages through increasing concentrations of ethanol followed by absolute acetone or (ii) increasing concentrations of hexylene glycol. The material was gradually infiltrated with Araldite 6005 by the method of Richardson et al. (33). Alternatively, the low viscosity epoxy resin described by Spurr (36) was used. Polymerization was carried out at 60 to $70 \mathrm{C}$ for 20 to $60 \mathrm{~h}$. Sections were stained for 10 to $20 \mathrm{~min}$ with lead citrate (32) and examined with a JEM 7A/120 electron microscope operated at $80 \mathrm{kV}$.

Observation of spore surface. Formvar-coated grids were dropped on part of Chainia colonies which had aerial hyphae. Some chains of conidia stuck to the Formvar and were observed with an Akashi TRS-50 electron microscope.

Thick sectioning. Araldite-embedded colonies were glued to a plastic rod which was held with a jeweler's vise and placed in the field of vision of a $40 \mathrm{x}$ stereoscopic microscope. Sectioning was done freehand with a fine scalpel. Sections were mounted under cover slip in immersion oil and were observed with a phase-contrast microscope.

\section{RESULTS}

Chainia sp. strain V17676 was sent to us by E. Tejera because of the beauty of the sclerotia formed and the abundance of lipid they contained. Comparison of the physiology and morphology of strain V17676 with other strains of chainiae showed it to be closest to two strains of $C$. olivacea (S and 3751) (Table 1). Chainiae are similar to streptomycetes in cell wall composition and in mode of sporulation; however, none of the strains tested could be identified with any of the species of Streptomyces which have been characterized by the methods of Gordon (16).

C. olivacea V17676 slowly lost its ability to form sclerotia upon continued cultivation on laboratory media. During the course of this study, fresh strains were obtained periodically from our freeze-dried stock. When formed, sclerotia were abundantly produced on $\mathrm{PC}, \mathrm{Cz}$, and YD agars. Production of sclerotia was best on TPab and TPC agars where hyphal growth was minimal. In old plate cultures (2-week-old or more), the surface of the agar was covered with a thick layer of yellow sclerotia which could be easily scraped off.

When spores and hyphal fragments were placed on TPab agar, hyphal development took place with the formation of radiating colonies typical of actinomycetes. After 18 to $20 \mathrm{~h}$ it was difficult, using a light microscope, to resolve the individual hyphae at the center of the colonies (Fig. 1a) at the location where, upon further incubation (Fig. 1b), the sclerotia would eventually grow. These sclerotia were at first tan and then, on maturing, yellow. Normally a number of sclerotia were formed at the center of a colony (Fig. 1 c). As the colony grew, the sclerotia increased in size and new sclerotia initials were formed at some distance from the center maturing into a "fairy ring" of sclerotia (Fig. 1d). In some large and old colonies, more than one such fairy ring could be produced. Four-day-old sclerotia were spherical and 50 to $75 \mu \mathrm{m}$ in diameter.

If a sclerotium was removed with a sterile fine point and placed on the surface of a TPab agar plate, germination of the sclerotium did not take place; rather, the few hyphae present on the surface of the sclerotium grew out radially and, after a few hours, the colony so formed was similar to the one from which the sclerotium had come. In other terms, a sclerotium on a nutritive medium could produce a colony without apparent use of its own nutritional resources, and the colony formed from a sclerotium could not be distinguished from one which had formed such a structure. Sclerotia placed on WA prepared with Noble agar and distilled water behaved in the same fashion, indicating that there were still enough impurities in the medium to allow growth of the actinomycetes without apparent wasting of the sclerotia.

After 9 days of incubation on TPab, numer- 


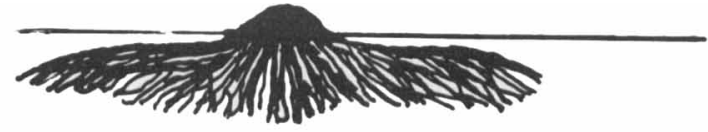

1 a
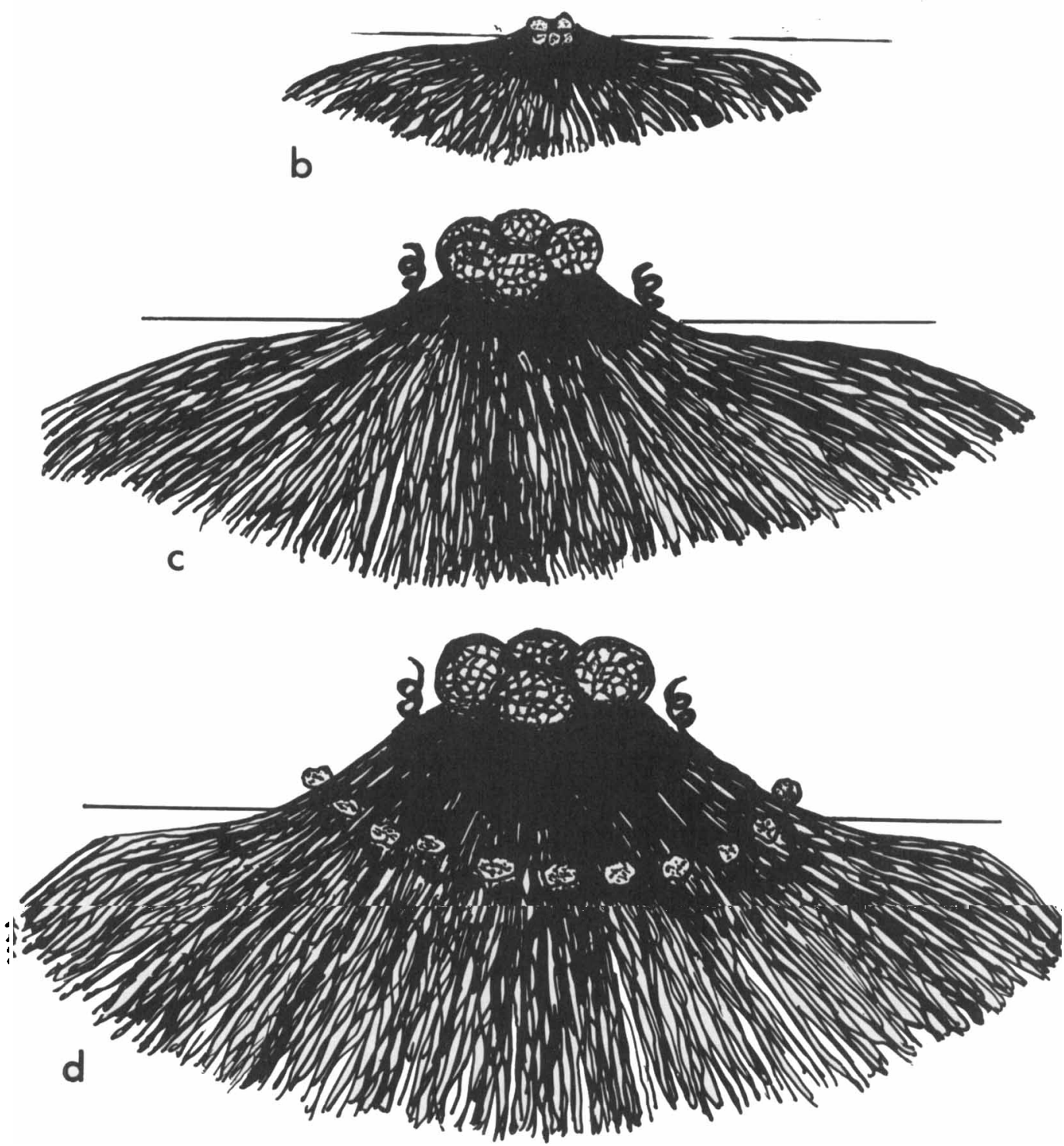

FIG. 1. Steps in the formation of sclerotia by Chainia olivacea strain V17676 on solid media. a, Young colony, 15-h-old. Hyphal structure visible in the whole colony except the very center. b, 20-h-old. Sclerotia initials are developing on top. $c, 24-$ to 48 -h-old. Sclerotia well developed. Coils of aerial hyphae are visible. $d, 48$ $h$ and more. Formation of a fairy ring of new sclerotia. 
ous tufts of white aerial hyphae were observed which contained chains of conidia in open spirals. Observed with an electron microscope, the conidia were found to have a smooth surface.

When sclerotia of $C$. olivacea were crushed between a slide and a cover slip, many oil droplets were released. If the pressing was thorough enough to dislodge most of the oil, a honeycomb-shaped plurilocular structure was observed (Fig. 2).

When grown in $\mathrm{Cz}$ shaken liquid medium at $28 \mathrm{C}$, the organism formed sclerotia-like bodies which were usually more elongated than spherical (about 100 by $250 \mu \mathrm{m}$ ). Upon crushing, these pseudosclerotia released oil droplets and a mass of short hypahe. No plurilocular structure was observed.

To gain some insight into the mode of formation of sclerotia, 20-h-old colonies grown on TPab agar at $25 \mathrm{C}$ were excised, fixed, dehydrated, and embedded in Araldite resin. At that age, the colonies were just starting to show signs of differentiation at their centers as in Fig. $1 \mathrm{~b}$. These resin-embedded colonies were first sectioned free hand, and the sections were observed by phase microscopy. The alveolar structure of the sclerotia initials could be seen surrounded by a granular area where the hyphal structure could no longer be resolved (Fig. 3); further away, the hyphae were clearly visible.

Ultrathin sections were made and observed with the electron microscope. The first step in the formation of sclerotia is the appearance of numerous amorphous inclusions in hyphae (Fig. 4). These are probably oil droplets. The lipid-rich hyphae contain numerous mesosomes and undergo repeated divisions leading to a cellular-like structure (Fig. 5, 6, and 7), which may be equated with the granular region seen in light microscopy surrounding the plurilocular area. As the cells fill with lipid, an amorphous material is deposited between the cell walls (Fig. 8). This amorphous material probably becomes the matrix of the plurilocular structure (PS). As the sclerotium matures further, the walls of the PS become increasingly more difficult to section. In a given sclerotium, the center, presumably the most mature portion, was the hardest to section. The cells of the PS became completely filled with lipids (Fig. 9), and eventually regrowth of hyphae took place in the cells (Fig. 10). (The overall process is summarized schematically in Fig. 11 a to e.)

All the Chainia strains listed in Table 1 had a Type I cell wall (26). In the case of V17676, it was found, however, that hydrolysates of the walls of sclerotia as well as of hyphae contained an additional amino acid besides those characteristic of cell walls of Type I. This compound has been shown to be $L$-2,3-diaminopropionic acid $\left(L-D A P_{r}\right)$. The free amino acid was compared with authentic DAP $_{\mathbf{r}}$ on the basis of color reaction with ninhydrin (bright blue when heated at about $120 \mathrm{C}$ ) and rate of migration in chromatography systems 2 and 3 . In system 2 , both compounds had an $R_{\text {glutamic acid of }}$ 0.84 after $48 \mathrm{~h}$. In system 3 they had an $R_{\mathrm{L}-\mathrm{d} \text { iaminopimelic acid }}$ of 0.93 . The mixture of DNP derivatives of the cell-wall amino acids showed a spot migrating with authentic $\mathbf{D A P}_{\mathbf{r}^{-}}$ DNP in systems 4 and 5 . Incubation of purified DAP $_{r}$ isolated from hydrolysates of sclerotia with D-amino acid oxidase showed no disappearance of the compound; hence, its isomeric configuration is of the $\mathrm{L}$ series.

Other strains of Chainia species, namely $C$. antibiotica and $C$. purpurogena, from which sclerotia could be obtained in large amounts, also contained DAP $_{\mathbf{r}}$. It is also of interest that hyphae from submerged growth of a V17676 substrain which had largely lost its capacity to form sclerotia showed only traces of this compound, whereas hyphae of a substrain still producing sclerotia contained substantial amounts. It is possible that the $\mathrm{DAP}_{r}$ is contained in the "cement" between the cells.

The amount of lipids contained in the sclerotia and hyphae of V17676 is presented in Table 2. Similar figures for lipids extracted from dried cells of representatives of the genera Mycobacterium and Nocardia, both of the order Actinomycetales and both known to produce large amounts of these substances, are included for comparison. As can be seen, V17676 is extraordinarily lipid rich. The Chainia figures are from cells grown on Czapek's medium (agar for sclerotia, liquid for hyphae), a medium in which sclerotia production (and hence lipid production) is optimal. The Mycobacterium and Nocardia strains were grown on YD because they do not grow well on Czapek's liquid. The lipid content of the Mycobacterium would probably increase on longer incubation. An average of 19\% (dry weight) for eight strains of mycobacteria grown in Sauton's medium for 4 to 6 weeks has been reported (1). Members of the genus Streptomyces, which is closely related to Chainia, contained only 0.56 to $2.7 \%$ lipids (1).

The lipids of Chainia olivacea strain V17676 are triglycerides of branched-chain fatty acids of the iso/anteiso series, principally $C_{15}$ and $\mathrm{C}_{16}$ with lesser amounts of $\mathrm{C}_{13}, \mathrm{C}_{14}$ and $\mathrm{C}_{17}$. 

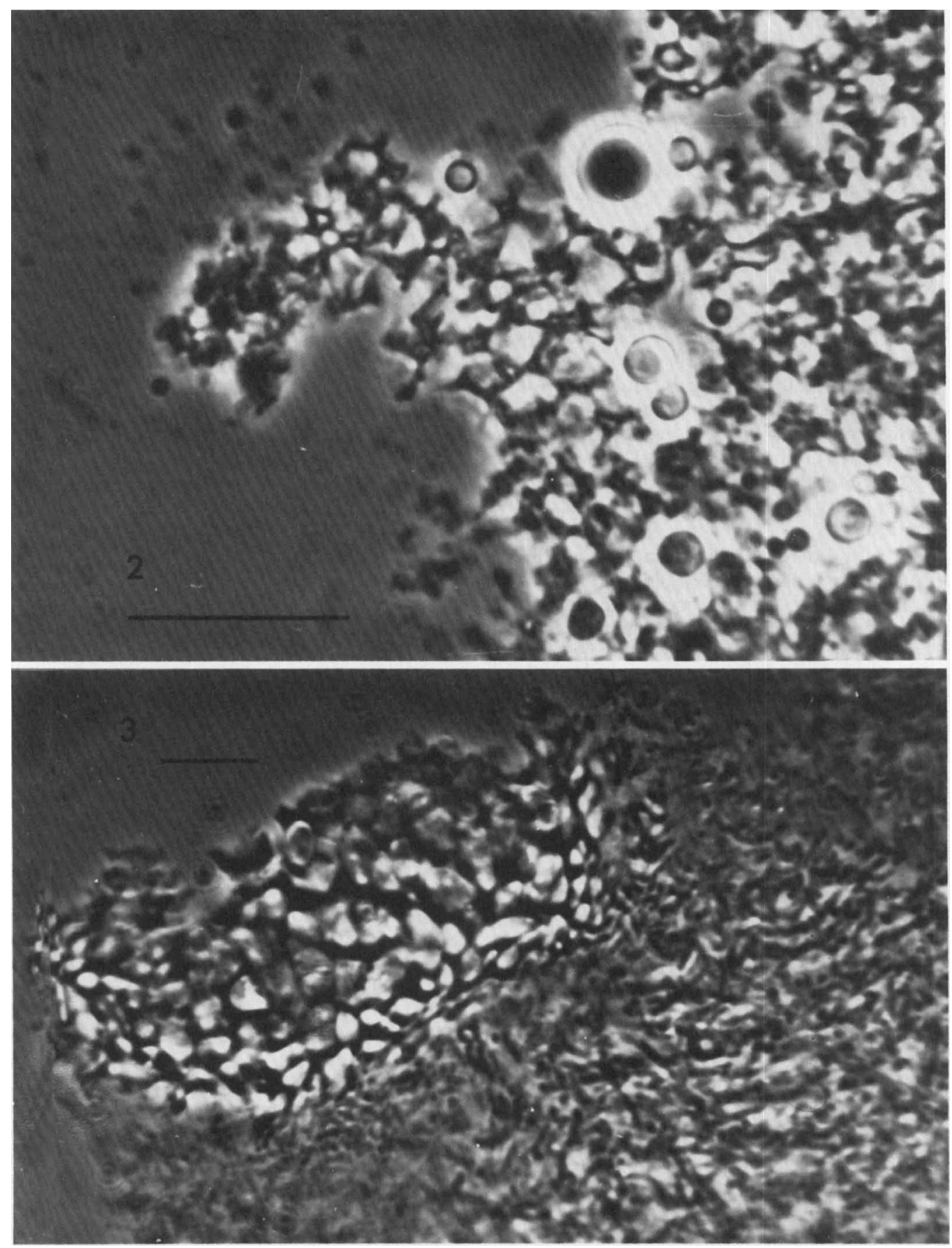

FIG. 2. Crushed 48-h-old sclerotium of $C$. olivacea grown on TPab. Immersion objective, phase contrast. Note plurilocular structure and oil droplets. Bar, $10 \mu \mathrm{m}$.

FIG. 3. Section through an 18-h-old sclerotium of C. olivacea grown on TPab. Immersion objective, phase contrast. Note plurilocular structure with adjoining granular area. Bar, $10 \mu \mathrm{m}$.

FIG. 4. Branched hyphe found in sclerotium-forming cultures of C. olivacea grown on TPab for 6 days at 28 C. Large inclusions which appear to be lipid droplets nearly fill the cell. Fixation was for $18 h$ in a glutaraldehyde-osmium tetroxide solution, followed by $3 \mathrm{~h}$ in $\mathrm{OsO}_{4}$ and $3 \mathrm{~h}$ in uranyl acetate. Dehydration was in ethanol, then acetone; embedding was in Araldite 6005. Sections were stained with lead citrate. Bar, $1 \mu \mathrm{m}$.

FIG. 5. Thin section through a young sclerotium of $C$. olivacea grown on TPab for $20 \mathrm{~h}$ at $28 \mathrm{C}$. Sclerotia were fixed in a formaldehyde-glutaraldehyde mixture for $17 \mathrm{~h}$, followed by $2 \mathrm{~h}$ in $\mathrm{OsO}_{4}$, and $3 \mathrm{~h}$ in uranyl acetate. Dehydration was in hexylene glycol, and embedment was in the " $A$ " mixture of Spurr. Sections were stained with lead citrate. Bar, $1 \mu \mathrm{m}$.

FIG. 6. Thin section through a young sclerotium of $C$. olivacea. Fixation and staining as for specimen shown in Fig. S. Bar, $1 \mu \mathrm{m}$. 

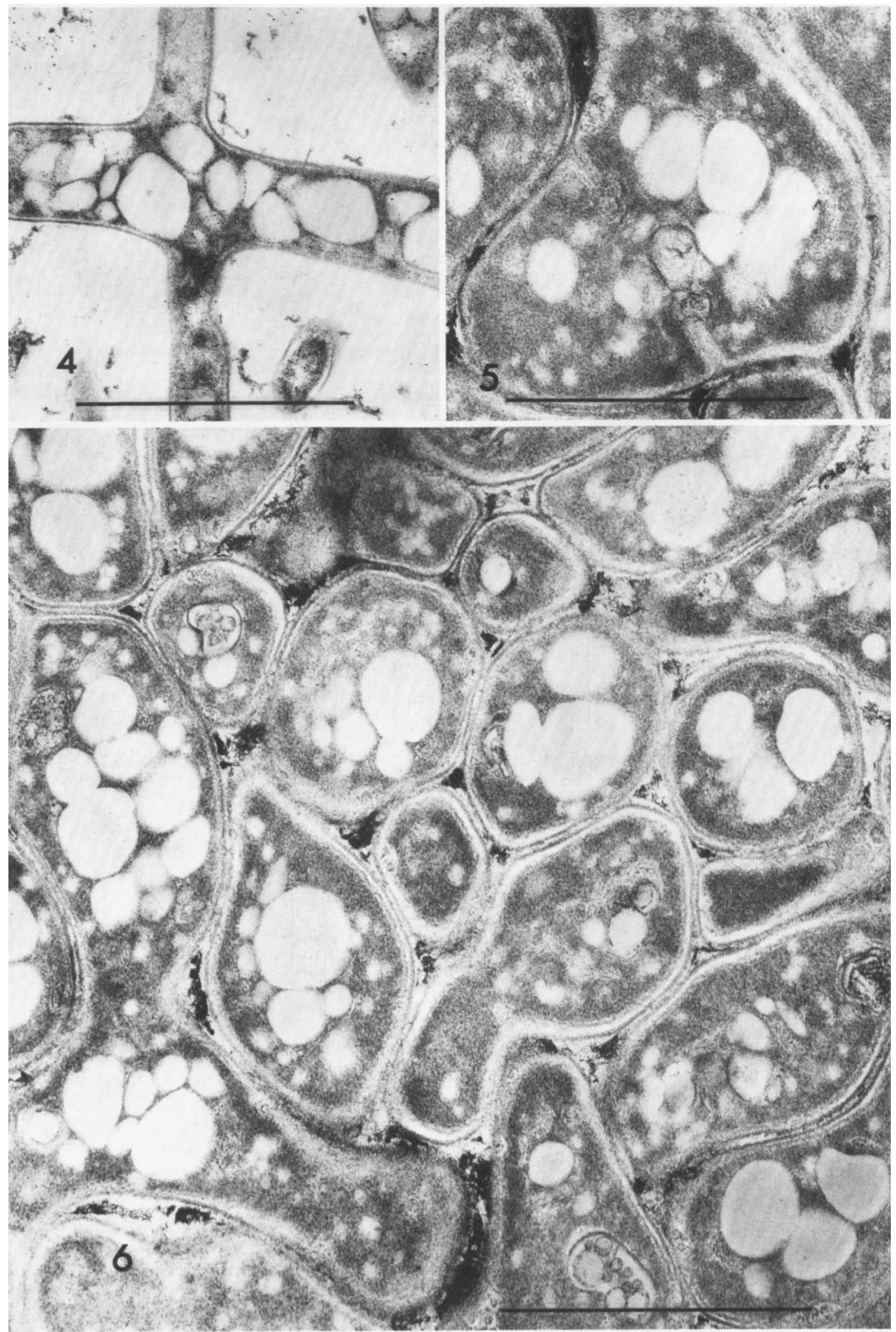

FIG. 4 to 6 . 

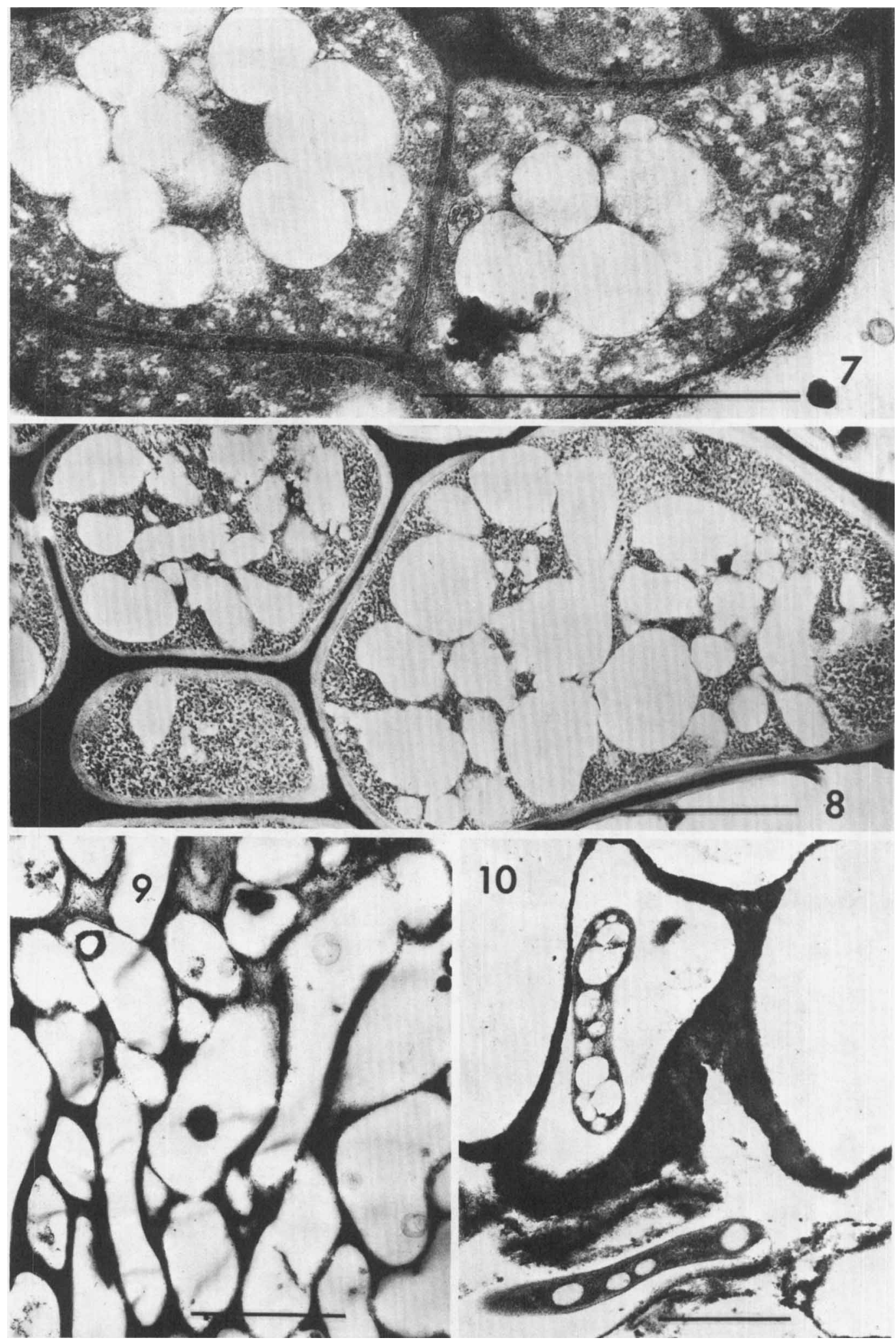

FIG. 7. Thin section through a sclerotium of $C$. olivacea grown on TPab for 7 days at 28 C. Fixation was in formaldehyde plus glutaraldehyde for $18 \mathrm{~h}$ followed by $\mathrm{OsO}_{4}$ for $2 \mathrm{~h}$, and then $3 \mathrm{~h}$ in uranyl acetate. Dehydration was in hexylene glycol. Spurr " $E$ " mixture was used for embedding. Staining of the sections was with lead citrate followed by 5 min in $2 \%$ aqueous barium permanganate. Bar, $1 \mathrm{\mu m}$.

FIG. 8. Thin section of a sclerotium of $C$. ochracea grown on TPab at $28 \mathrm{C}$ for 6 days and then fixed in formaldehyde and glutaraldehyde for $18 \mathrm{~h}$. Postfixation was in $\mathrm{OsO}_{4}$ for $3 \mathrm{~h}$ followed by staining in uranyl 

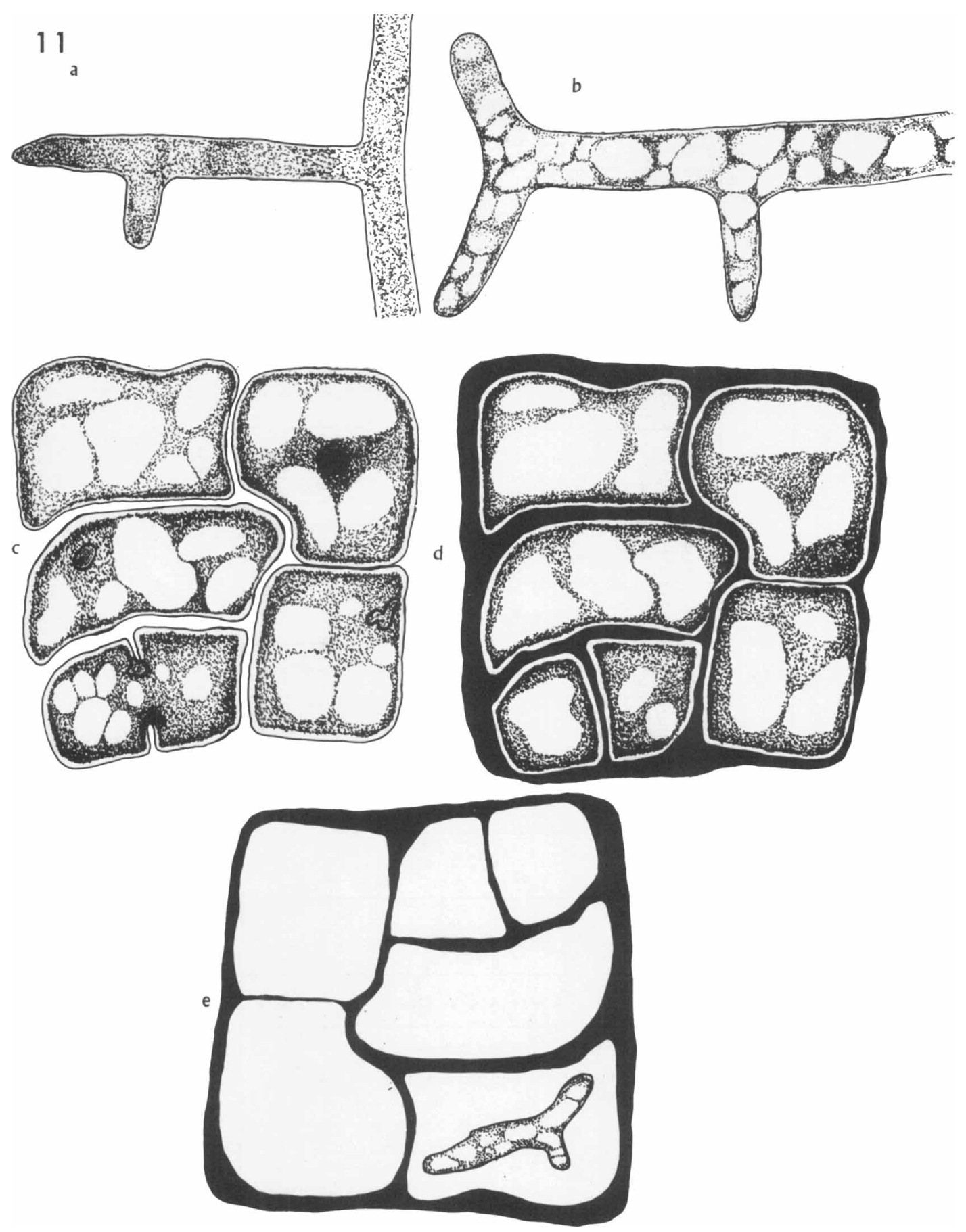

FIG. 11. Steps in the formation of sclerotia of C. olivacea: young hypha (a); hypha becoming filled with lipid inclusions (b); hyphae swell and divide, forming a mass of lipid-rich cells, mesosomes are numerous (c); deposition of intercellular cement (d); all cellular material has been transformed into lipids, there is regrowth of a few hyphae in some of the cells $(e)$.

acetate for $3 \mathrm{~h}$. Dehydration was in ethanol followed by acetone, and embedment was in Araldite 6005 . Sections were stained with lead citrate. Bar, $1 \mu \mathrm{m}$.

FIG. 9. Thin section of a sclerotium of $C$. ochracea grown on YD for 6 days at $28 C$. The preparative procedure was like that described for the specimen shown in Fig. 8 with the exception of the initial fixative, which was glutaraldehyde and osmium tetroxide in this instance. Bar, $1 \mu \mathrm{m}$.

FIG. 10. Thin section of a sclerotium of $C$. ochracea grown on TPab for 7 days at 28 C. Fixation was in formaldehyde and glutaraldehyde for $18 \mathrm{~h}$ followed by $\mathrm{OsO}_{4}$ for $2 \mathrm{~h}$ and then staining with uranyl acetate at room temperature for $3 \mathrm{~h}$. Dehydration was in ethanol and acetone, and embedment was in Spurr mixture "E." Sections were stained with lead citrate and barium permanganate. Bar, $1 \mu \mathrm{m}$. 
TABLE 1. Biochemical properties of strains of Chainia

\begin{tabular}{|c|c|c|c|c|c|c|c|c|c|c|c|c|c|c|c|c|c|}
\hline \multirow[b]{2}{*}{ Strain $^{a}$} & \multirow[b]{2}{*}{$\begin{array}{c}\text { Hydrol- } \\
\text { ysis of } \\
\text { xan- } \\
\text { thine }\end{array}$} & \multirow[b]{2}{*}{$\begin{array}{c}\text { Utili- } \\
\text { zation of } \\
\text { oxalate }\end{array}$} & \multicolumn{2}{|c|}{$\begin{array}{l}\text { Pro- } \\
\text { duction } \\
\text { of: }\end{array}$} & \multicolumn{10}{|c|}{ Acid from: } & \multicolumn{2}{|c|}{$\begin{array}{l}\text { Growth } \\
\text { at: }\end{array}$} & \multirow[b]{2}{*}{$\begin{array}{c}\text { Sur- } \\
\text { vival: } \\
50 \mathrm{C} \text {, } \\
8 \mathrm{~h}\end{array}$} \\
\hline & & & $\begin{array}{l}\text { Ure- } \\
\text { ase }\end{array}$ & $\begin{array}{l}\mathrm{Ni}- \\
\text { trate } \\
\text { reduc- } \\
\text { tase }\end{array}$ & $\begin{array}{c}\text { Adon- } \\
\text { itol }\end{array}$ & $\begin{array}{l}\text { Eryth- } \\
\text { ritol }\end{array}$ & $\begin{array}{c}\text { Inos- } \\
\text { itol }\end{array}$ & $\begin{array}{l}\text { Lac- } \\
\text { tose }\end{array}$ & $\begin{array}{l}\text { Man- } \\
\text { nitol }\end{array}$ & $\begin{array}{l}\text { Mel- } \\
\text { ibi- } \\
\text { ose }\end{array}$ & $\begin{array}{c}\alpha \text {-Methyl- } \\
\text { gluco- } \\
\text { side }\end{array}$ & $\begin{array}{l}\text { Raf- } \\
\text { finose }\end{array}$ & $\begin{array}{c}\text { Rham- } \\
\text { nose }\end{array}$ & $\begin{array}{l}\text { Xy- } \\
\text { lose }\end{array}$ & $10 \mathrm{C}$ & $42 \mathrm{C}$ & \\
\hline C. antibiotica $\mathrm{Su} 7(\mathrm{~S})^{b}$ & + & + & + & - & + & + & + & + & + & + & + & + & + & + & - & + & + \\
\hline C. antibiotica 3750 & + & + & + & + & - & - & + & + & + & + & + & + & + & + & - & + & + \\
\hline C. aurea $\mathrm{Su} 8(\mathrm{~S})$ & - & - & + & - & - & - & - & + & + & - & + & - & + & + & - & + & + \\
\hline C. flava Su 9 (S) & - & + & + & - & - & - & - & + & + & - & + & - & + & + & - & + & + \\
\hline C. fumigata SU 10 (S) & + & + & + & - & - & - & - & + & + & + & + & + & + & + & - & + & + \\
\hline C. minutisclerotica Su $11(\mathrm{~S})$ & - & + & + & - & - & - & + & + & + & - & + & - & + & + & - & + & + \\
\hline C. nigra $\mathrm{Su} 12$ (S) & + & + & + & + & + & + & + & + & + & + & + & + & + & + & - & + & + \\
\hline C. ochracea Su 13 (S) & + & + & + & - & + & + & + & + & + & + & + & - & + & + & + & - & + \\
\hline C. olivacea $\mathrm{Su} 14(\mathrm{~S})$ & + & + & - & - & - & + & + & + & + & - & + & + & + & + & - & - & + \\
\hline C. olivacea $3751 \mathrm{Lyo}^{c}$ & + & + & + & + & + & + & + & + & + & + & + & + & + & + & - & + & + \\
\hline C. olivacea 3751 & + & + & + & + & + & + & + & + & + & + & + & + & + & + & - & + & + \\
\hline C. poonensis Su 15 (S) & + & + & - & + & - & - & + & + & + & - & + & - & + & + & - & - & + \\
\hline C. poonensis 3752 & + & - & - & - & - & + & - & - & - & - & - & - & - & - & - & - & - \\
\hline C. purpurogena Su 16 (S) & + & - & + & + & + & + & + & + & + & + & + & + & + & + & + & + & + \\
\hline C. rosea $\mathrm{Su} 17(\mathrm{~S})$ & - & + & - & - & - & - & + & + & + & + & + & - & + & + & - & + & + \\
\hline C. olivacea $\mathrm{V} 17676$ & + & + & + & + & + & + & + & + & + & - & + & + & + & + & - & - & + \\
\hline C. olivacea V17676 Lyo & + & + & + & + & + & + & + & + & + & - & + & + & + & + & - & - & + \\
\hline
\end{tabular}

${ }^{a}$ For all strains, hydrolysis of casein, hypoxanthine, adenine, starch and gelatin was positive; utilization of citrate, malate and succinate was positive; none of the strains grew in salicylate broth; acid was produced from galactose, glucose and mannose; all strains grew at $37 \mathrm{C}$; none grew at $53 \mathrm{C}$.

${ }^{b}$ S, From R. S. Sukapure.

$c$ Culture freshly revived from freeze-dried state. 


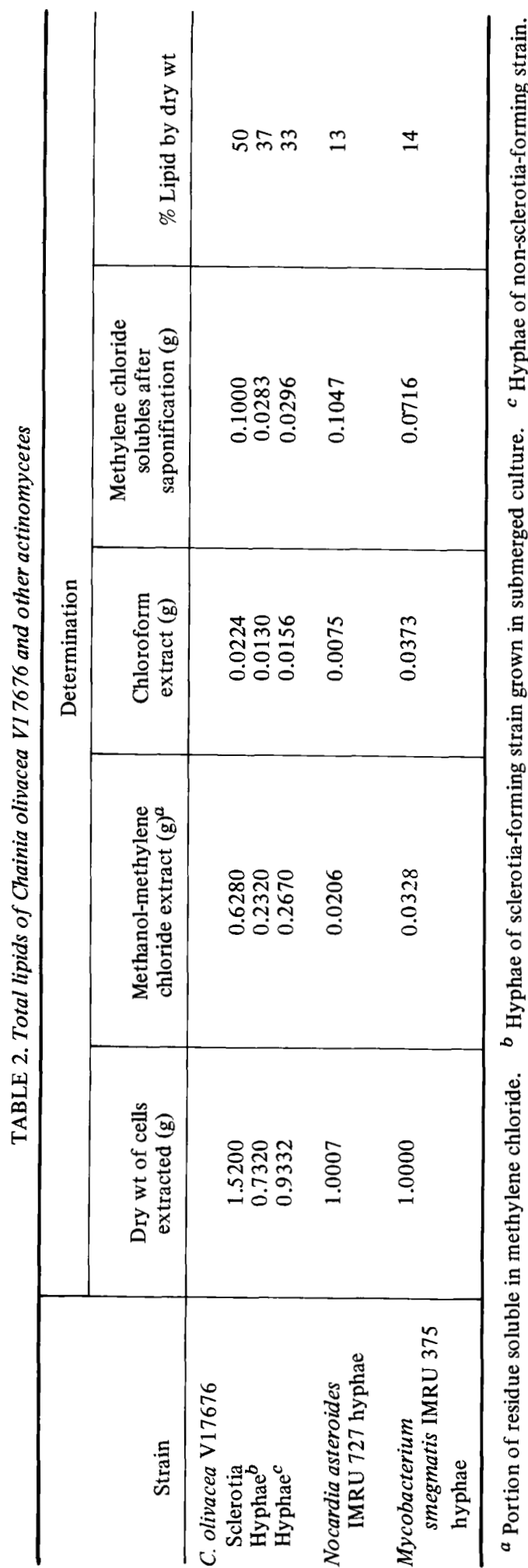

This pattern is similar to the type of fatty acids reported from the closely related streptomycetes (1). The identification of the fatty acids was based on retention times of the methyl esters compared with authentic compounds on GLC and the lack of reaction in the solvomercuration-demercuration reaction. Glycerol was identified by its $R_{F}$ in systems 1 and 2 by comparison with the known compound and by its reaction with the Bean-Porter reagent.

On thin-layer chromatography (TLC) in system 6, the crude lipid extracted from V17676 sclerotia migrated as a single major spot corresponding in $R_{F}$ to standard triglycerides. No compounds reacting with ninhydrin or the molybdenum blue reagent for phospholipids were found. Saponification of the crude lipid yielded compounds migrating on TLC plates like normal fatty acids. Methylation of the saponified residue yielded a mixture which showed one major spot on TLC corresponding to the methyl esters of normal fatty acids and two minor, more polar, spots of unknown composition, possibly corresponding to the $\alpha$-hydroxy fatty acids reported from streptomy cetes (25).

Some strains of Chainia have been isolated from relatively hostile environments such as deserts (personal communication, R. S. Sukapure), but this is not true for all strains of Chainia, including V17676. In an attempt to determine whether the sclerotia play a role in heat resistance, both sclerotia and vegetative cells of V17676 were compared with the vegetative cells of Streptomyces fradiae IMRU 3535. The results (Table 3 ) show that sclerotia are not only more heat resistant than cells of the streptomycete but also more resistant than hyphae of V17676 itself.

Prolonged digestion of sclerotia with lysozyme did not alter their appearance when viewed with the light microscope. However, acid hydrolysates of such sclerotia which had been delipidated by extraction with methylene chloride showed that the muramic acid, glucosamine, and $\mathrm{L}$-diaminopimelic acid had largely disappeared, as did some of the glutamic acid. The major components remaining were $\mathrm{DAP}_{\mathbf{r}}$, aspartic acid, lysine, serine, glycine, alanine, and galactosamine, which we assume are the main constituents of the intercellular "cement."

\section{DISCUSSION}

2,3-Diaminopropionic acid ( $\beta$-amino alanine) has been found previously in nature but not, as 
TABLE 3. Heat resistance of sclerotia and hyphae of Chainia olivacea V17676 and of hyphae of Streptomyces fradiae IMRU 3535

\begin{tabular}{l|c|c|c|c}
\hline \multicolumn{1}{c|}{ Strain } & $60 \mathrm{C} / 4 \mathrm{~h}$ & $70 \mathrm{C} / 15 \mathrm{~min}$ & $70 \mathrm{C} / 30 \mathrm{~min}$ & $96 \mathrm{C} / 1 \mathrm{~min}$ \\
\hline $\begin{array}{l}\text { V17676 } \\
\text { Sclerotia }\end{array}$ & $+^{a}$ & + & + & - \\
$\begin{array}{l}\text { Hyphae } \\
\text { 355 }\end{array}$ & $-{ }^{b}$ & - & - & - \\
Hyphae & - & - & - & - \\
\hline
\end{tabular}

$a+$, Growth.

$b_{-, \text {No growth. }}$

far as we know, in the structural components of a microorganism. There have been reports of this amino acid either free or oxalylated from seeds of plants $(6,15,30,42)$. It has also been found free (as the $D$ isomer) in the digestive fluid of Bombyx mori (43) and as a constituent of the antibiotics edeine ( $L$-isomer) (34), viomycin ( $L$-isomer) $(19,43)$, and capreomycin (20). The last two antibiotics are produced by actinomycetes.

Structures formed by eubacteria which are resistant to adverse conditions include endospores and cysts. Actinomycetes are bacteria having a fungoid morphology; thus, they form not only endospores (9) like bacteria but also sclerotia, like fungi. The structure of the sclerotia of Chainia is different from that of other structures formed by actinomycetes. Perhaps it is closest to that of the vesicles of the endophytes now placed in the genus Frankia (5, 12).

In fungi, sclerotia are firm aggregations of vegetative hyphae containing reserve materials. They can be rich in carbohydrates, such as those of Phymatotrichum omnivorum, or in lipids, such as those of Claviceps purpurea. After maturity, sclerotia are capable of independent persistence. They germinate at the expense of the reserve materials by producing either hyphae, as in P. omnivorum; spores, as in species of Botrytis; or carpophores, as in species of Claviceps $(7,8)$.

The heat tolerance of sclerotia of strain V17676 supports the assumption that formation of sclerotia by chainiae helps these organisms to survive under adverse conditions. The heat resistance of the sclerotia is, however, quite modest when compared with that of spores of Thermoactinomyces vulgaris, which can withstand $45 \mathrm{~min}$ at $100 \mathrm{C} \mathrm{(9).} \mathrm{It} \mathrm{is}$ essentially of the same order of magnitude as that of spores of streptomycetes (45). We have not been able to demonstrate that the lipids stored in the sclerotia of strain V17676 were actually used for growth. Even on the most meager medium we used, some growth took place without any apparent wasting of the sclerotia. This may be due to the fact that actinomycetes in general are able to grow at the expense of only minute amounts of nutrients or that the rigid structure of sclerotia does not break down even though the lipids are utilized.

In light of our results, the actual role of sclerotia of strains of Chainia is not clear. The sclerotia are somewhat heat resistant and contain substantial amounts of triglycerides; however, the role of the lipids as storage materials is not obvious. The production of sclerotia probably does not confer any apparent ecological advantage over the production of spores of the type produced by streptomycetes.

Should sclerotia-forming organisms with a cell wall of Type I (Streptomyces type) be placed in a special genus? The property of producing sclerotia is easily lost upon cultivation on laboratory media, and a nonsclerotial strain of Chainia cannot be differentiated from a streptomycete. In addition, to complicate matters further, some members of the order Actinomycetales with Type IV cell walls also produce sclerotia (M. P. Lechevalier, unpublished results). However, until it has been demonstrated experimentally that "ordinary streptomycetes" can be induced to form truly plurilocular sclerotia, we favor recognizing Chainia as a distinct genus.

\section{ACKNOWLEDGMENTS}

This work was partially supported by National Science Foundation Grant GB 18705.

The authors wish to thank all those who sent us strains of Chainia, B. Ghosh for advice on electron microscope problems, N. N. Gerber for suggesting the solvomercuration-demercuration technique, and Eva Fekete and Magda Gagliardi for technical assistance. 


\section{REPRINT REQUESTS}

Address requests for reprints to: Mary $P$. Lechevalier, Institute of Microbiology, Rutgers University, the State University of New Jersey, New Brunswick, N. J. 08903.

\section{LITERATURE CITED}

1. Asselineau, J. 1966. The bacterial lipids. Hermann, Paris.

2. Baldacci, E., R. Locci, and J. R. Locci. 1966. Production of "granules" by Actinomycetales. Giorn. Microbiol. 14:173-184.

3. Bean, R. C., and G. G. Porter. 1959. Detection and differentiation of sugars and polyols on single paper chromatograms. Anal. Chem. 31:1929-1930.

4. Becker, B., M. P. Lechevalier, and H. A. Lechevalier. 1965. Chemical composition of cell-wall preparations from strains of various form-genera of aerobic actinomycetes. Appl. Microbiol. 13:236-243.

5. Becking, J. H. 1970. Frankiae fam. nov. with one new combination and six new species of the genus Frankia. Int. J. Syst. Bacteriol. 20:201-220.

6. Bell, E. A., and A. S. L. Tirimanna. 1965. Associations of amino acids and related compounds in the seeds of 47 species of Vicia: their taxonomic and nutritional significance. Biochem. J. 97:104-111.

7. Butler, G. M. 1966. Vegetative structures, p. 83-112. In G. C. Ainsworth and A. S. Sussman (ed.), The fungi, vol. 2. Academic Press Inc., New York.

8. Coley-Smith, J. R., and R. C. Cooke. 1971. Survival and germination of fungal sclerotia. Annu. Rev. Phytopathol. 9:65-92.

9. Cross, T. 1968. Thermophilic actinomycetes. J. Appl. Bacteriol. 31:36-53.

10. Cross, T., M. P. Lechevalier, and H. Lechevalier. 1963. A new genus of the Actinomycetales: Microellobosporia gen. nov. J. Gen. Microbiol. 31:421-429.

11. Franke, W. W., S. Krien, and R. M. Brown. 1969. Simultaneous glutaraldehyde-osmium textroxide fixation with postosmication. Histochemie 19:162-164.

12. Gardner, I. C. 1965. Observation on the fine structure of the endophyte of the root nodules of Alnus glutinosa. Arch. Mikrobiol. 51:365-383.

13. Gattani, M. L. 1957. Production of sclerotic granules by Streptomyces sp. Nature (London) 180: 1293-1294.

14. Gerber, N. N. 1972. Sesquiterpenoids from actinomy cetes. Phy tochemistry 11:385-388.

15. Gmelin, R., G. Strauss, and G. Hasenmaier. 1959. Über neue Aminosäuren aus Mimosaceen HoppeSeyler's Zeit. f. Physiol. Chem. 314:28-32.

16. Gordon, R. E. 1967. The taxonomy of soil bacteria, p. 293-321. In T. R. G. Gray and D. Parkinson (ed.), The ecology of soil bacteria. Liverpool University Press, Liverpool.

17. Gordon, R. E., and A. C. Horan. 1968. A piecemeal description of Streptomyces griseus (Krainsky), Waksman and Henrici. J. Gen. Microbiol. 50:223-233.

18. Grant, W. D., and A. J. Wicken. 1970. Thin-layer and paper chromatography of dinitrophenyl derivatives of amino acids from bacterial cell wall peptidoglycan. J. Chromatog. 47:124-126.

19. Haskell, T. H., S. A. Fusari, R. P. Frohardt, and Q. R. Bartz. 1952. The chemistry of viomycin. J. Amer. Chem. Soc. 74:599-602.

20. Herr, E. B., Jr. 1963. Chemical and biological properties of capreomycin and other peptide antibiotics. Antimicrob. Ag. Chemother. 1962, p. 201-212.

21. Higgins, M. L., M. P. Lechevalier, and H. A. Lechevalier. 1967. Flagellated actinomycetes. J. Bacteriol. 93:1446-1451.

22. Kalakoutskii, L. V., and N. A. Krassilnikov. 1960. The formation of sclerotia by actinomycetes and the systematic position of the genus Chainia (in Russian). Tr. Inst. Mikrobiol. Akad. Nauk SSSR 8:45-55.

23. Karnovsky, M. J. 1965. A formaldehyde-glutaraldehyde fixative of high osmolarity for use in electron microscopy. J. Cell. Biol. 27:137A-138A.

24. Kuznetsov, V. D. 1962. A new species of genus Chainia. Microbiology USSR 31:435-439.

25. Lanéelle, M.-A., J. Asselineau, and G. Castelnuovo. 1968. Relations chimiques et immunologiques chez les actinomycétales. IV. Composition chimique des lipides de quatre souches de streptomyces et d'une souche de N. (Str.) gardneri. Ann. Inst. Pasteur 114:305-312.

26. Lechevalier, H. A., M. P. Lechevalier, and N. N. Gerber. 1971. Chemical composition as a criterion in the classification of actinomyces, p. 47-72. In D. Perlman (ed.), Advances in applied microbiology, vol. 14. Academic Press Inc., New York.

27. Lechevalier, M. P. 1968. Identification of aerobic actinomy cetes of clinical importance. J. Lab. Clin. Med. 71:934-944.

28. Lechevalier, M. P., A. C. Horan, and H. Lechevalier. 1971. Lipid composition in the classification of nocardiae and mycobacteria. J. Bacteriol. 105:313-318.

29. Lechevalier, M. P., H. Lechevalier, and P. E. Holbert. 1968. Sporichthya, un nouveau genre de Streptomycetaceae. Ann. Inst. Pasteur 114:277-286.

30. Murakami, T., N. Mori, and M. Nagazawa. 1968. Studies on the water-soluble constituents of crude drugs. VI. Isolation and identification of $\gamma$ guanidinobutyric acid and a, $\beta$,diaminopropionic acid from semen of Trichosanthés cucumeroides. Yakugaku Zasshi 88:488-489.

31. Randerath, K. 1968. Thin-layer chromatography. Academic Press Inc., New York.

32. Reynolds, E. S. 1963. The use of lead citrate at high $\mathrm{pH}$ as an electron-opaque stain in electron microscopy. J. Cell. Biol. 17:208-212.

33. Richardson, K. C., L. Jarrett, and E. J. Finke. 1960. Embedding in epoxy resins for ultrathin sectioning in electron microscopy. Stain Technol. 35:313-323. 
34. Roncari, G., Z. Kurylo-Borowska, and L. C. Craig. 1966. On the chemical nature of the antibiotic Edeine. Biochemistry 5:2153-2159.

35. Shirling, E. B., and D. Gottlieb. 1972. Cooperative description of type strains of Streptomyces. V. Additional descriptions. Int. J. Syst. Bacteriol. 22:265-394.

36. Spurr, A. R. 1969. A low-viscosity epoxy resin embedding medium for electron microscopy. J. Ultrastruct. Res. 26:31-43.

37. Šuput, J., M. P. Lechevalier, and H. A. Lechevalier. 1967. Chernical composition of variants of aerobic actinomycetes. Appl. Microbiol. 15:1356-1361.

38. Thirumalachar, M. J. 1955. Chainia, a new genus of the Actinomycetales. Nature (London) 176:934-935.

39. Thirumalachar, M. J., P. W. Rahalkar, P. V. Deshmukh, and R. S. Sukapure. 1965. Production of aburamycin by Chainia minutisclerotica, a new species of actinomycetes. Hindustan Antibiot. Bull. 8:6-9.

40. Thirumalachar, M. J., and R. S. Sukapure. 1964. Studies on species of the genus Chainia from India. Hindustan Antibiot. Bull. 6:157-166.

41. Thirumalachar, M. J., R. S. Sukapure, P. W. Rahalkar, and K. S. Gopalkrishnan. 1966. Studies on species of the genus Chainia from India II. Hindustan Antibiot. Bull. 9:10-15.

42. Thompson, J. F., C. J. Morris, and I. K. Smith. 1969. New naturally occurring amino acids. Annu. Rev. Biochem. 38:137-158.

43. Wada, S., and T. Toyota. 1965. Isolation of D(-)-2,3-diaminopropionic acid from digestive fluid of silkworm larvae, Bombyx mori. Biochem. Biophys. Res. Commun. 19:482-486.

44. Waksman, S. A. 1950. The actinomycetes, p. 193. Chronica Botanica, Waltham, Mass.

45. Waksman, S. A. 1959. The actinomycetes, vol. I. Williams and Wilkins, Baltimore.

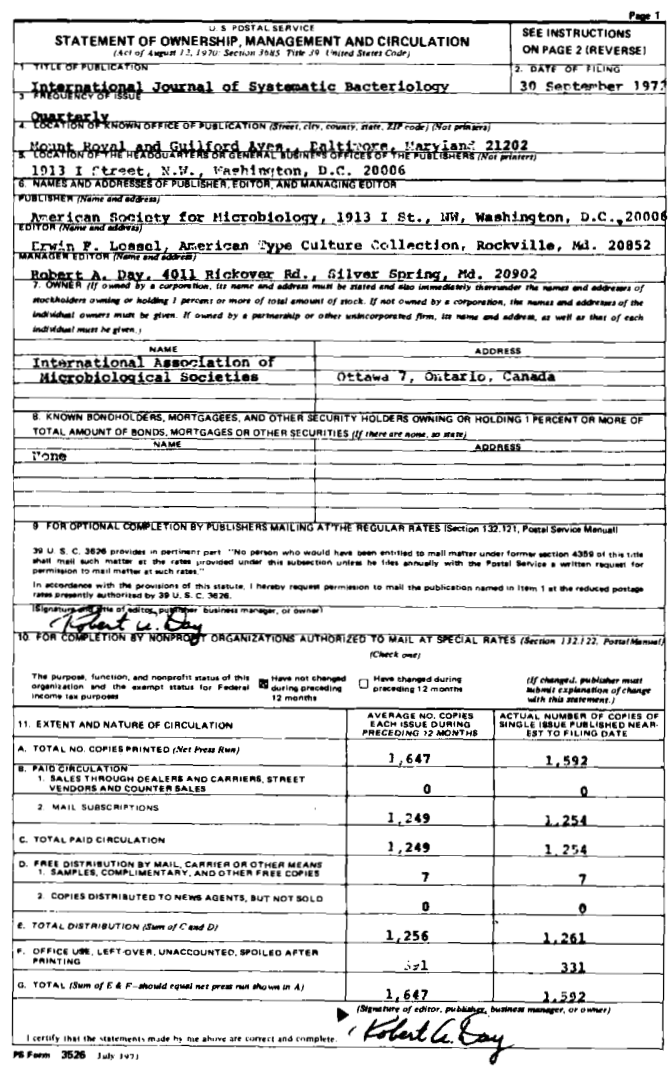

